\title{
Foreign Currency Deposits and International Liquidity Shortages in Pakistan
}

\section{Abbas Mirakhor and Iqbal Zaidi}

\section{Abstract}

This Working Paper should not be reported as representing the views of the IMF. The views expressed in this Working Paper are those of the author(s) and do not necessarily represent those of the IMF or IMF policy. Working Papers describe research in progress by the author(s) and are published to elicit comments and to further debate.

This paper studies the implications of foreign currency deposits (FCDs) for international liquidity shortages in Pakistan. The analysis focuses on how the large volume of FCDs and the specific institutional characteristics of those deposits have made the Pakistan economy highly vulnerable to exogenous shocks. The analysis shows that FCDs created another channel for government borrowing, and fiscal sustainability in a "closed" system may be very different from sustainability in a more "open" system. There is a need to think of these issues in terms of total balance sheet vulnerability, and we recommend measures that would make domestic-currency-denominated assets attractive to investors.

JEL Classification Numbers: E52; F41

Keywords: Capital Account Liberalization, Financial Development, Dollarization

1 Iqbal Zaidi is a Senior Economist in the IMF's Finance Department. The authors wish to thank Klaus Enders, Nuri Erbas, Robert Flood, David Goldsbrough, Michael Hadjimichael, Aasim Husain, and Mohsin Khan for comments on this paper.

\section{INTRODUCTION}

This paper focuses on several shortcomings in the way in which the capital account of the balance of payments in Pakistan was liberalized with the introduction of foreign currency deposits (FCD). The policymakers thought that the foreign currency deposits might be the answer to the low level of savings and investment in the economy, because these deposits could help to mobilize both domestic and external savings. However, the increase in potential savings from the FCDs did not result in a boom in investment, but instead these short-term foreign liabilities helped to finance large fiscal and external current account deficits for a somewhat longer period than would have been possible otherwise. The end result was that the country was saddled with a debt overhang problem, which severely constrained long-term growth prospects. The experience of Pakistan demonstrates the importance of public debt sustainability for maintaining economic stability and growth, and underlines the difficulties that borrowing governments face in assessing what are appropriate debt levels, that is, those that can be sustained, especially if there is a high degree of dollarization in the economy. The analysis attempts to pinpoint the central structural weaknesses in the financial system, focusing in particular on how short-term foreign liabilities have adversely affected the conduct of financial policies. 2 
The FCD scheme required banks to sell all of the foreign exchange deposited with them to

the State Bank of Pakistan (SBP), which in turn provided foreign exchange cover to the commercial banks. The SBP provided the forward cover at subsidized rates for almost all years during the operation of the original scheme, 3 and the foreign exchange earnings that could have gone into international reserve accumulation were instead used for financing persistent fiscal and external imbalances.4 The resulting open foreign exchange position 2 Our focus on FCDs is not meant to “put too much blame” on them as a cause of Pakistan's problems, instead by limiting our analysis to a few key factors, we hope to provide a more in-depth analysis of certain core issues

that are frequently mentioned in policy discussions, but that could benefit from a more rigorous treatment. Needless to say, this paper does not aim to cover all of the difficulties (e.g., terms of trade deterioration, sharp

fluctuations in capital inflows, droughts in some years, floods in some others, and political instability) that stymied the several attempts made by the authorities at introducing comprehensive stabilization and structural reform programs. Excellent and detailed accounts of what happened more broadly and what needs to be done in

Pakistan can be found elsewhere. See, for example, IMF (2001, 2002a, 2002b), IMF Independent

Evaluation

Office (2002), and World Bank (2002). See also the important contribution of Yaqub (2003), which not only

provides an authoritative analysis of monetary policy and banking sector reforms but also sheds light on the complex political environment in Pakistan.

3 The description of the FCD scheme in this paragraph is for (what might be termed for the lack of a better word) the "original” FCD scheme, which was in effect till May 1998, at which time the authorities imposed a

freeze on the convertibility of foreign currency deposits. Subsequently, a new set of regulations were issued for

FCDs, and these are sometimes called the "new" FCD deposits, and while these deposits have grown rapidly,

some of the problems such as the SBP providing forward cover are not present in the new scheme. In several instances we try to point out this crucial difference between the two regimes, but it should be kept in mind that

most of the discussion in this paper deals with the problems from the original scheme, although many of the same issues crop up with the new regime, including the need for self-protection policies to reduce the country's exposure to capital account crises.

4 This policy dilemma was a result of the fiscal pressures on monetary policy and the balance of payments, on

the one hand, and the way the FCD scheme was operated, on the other hand. Furthermore, since the SBP

was

(continued...)

- 4 -

became an increasingly difficult problem for the SBP with the continued growth of the FCDs, on the one hand, and the rundown of international reserves, on the other hand. The problem was made worse by the failure of the private sector to adequately insure against the

possibility of an international liquidity shortage (defined to be one where the external supply of funds is a vertical curve). This issue is discussed below in considerable detail in terms 
of

the Caballero-Krishnamurthy dual liquidity model, where the private sector underinsures against crisis events, and the extent of the underinsurance depends on the expectations about central bank actions during a crisis. Unfortunately, instead of taking either direct or indirect

ex-ante measures that would have encouraged the private sector to carry more international

liquidity into the crisis situation, the authorities were doing exactly the opposite, namely, encouraging the build-up of FCDs through preferential treatment (taxes, SBP provision of forward cover at subsidized rates, etc.). In particular, despite the private sector underinsurance problem and the high risks of international liquidity shortages, the authorities

left the international reserves at low levels; in fact, for many years they rarely met even the

rough rules of thumb for adequate reserve/import cover. By the mid-1990s, the authorities were facing not only a public sector debt that was reaching unsustainable proportions but also a nagging problem of inadequate international liquidity.

The paper is organized along the following lines. Following this section, Section II discusses

the effects of persistent fiscal deficits in Pakistan on domestic savings and external indebtedness. The discussion focuses on how the FCD scheme helped to mobilize savings but

only at the cost of putting severe strains on financial policies, which leads to the discussion of capital account liberalization and FCDs. Section III begins with a description of the evolution of the FCD scheme, then discusses the implications of the FCDs and dollarization

for the conduct of financial policies, and concludes by weighing the benefits from having large foreign currency deposits against their costs. This discussion of capital account liberalization, financial market distortions, and excessive volatility in asset prices during the

various episodes of near financial crises sets the stage for the prescriptions for optimal policy

responses to these crises, which are taken up in the following section. Section IV describes

the government's policy response to the various episodes of financial distress, focusing not

only on the steps that have been taken but also on what additional steps must be taken. Finally, Section V contains some brief concluding remarks, including a comment on the priorities for fiscal consolidation and the reform of the FCD scheme. The analytics of the Caballero-Krishnamurthy model and its implications for the FCD scheme in Pakistan are provided in the Appendix.

\section{Foreign CuRRENCY DEPOSITS, Fiscal DEFICITS, AND EXTERNAL DEBT}


Pakistan experienced protracted balance of payments problems throughout the 1980s and 1990s, reflecting the expansionary financial policies but also weaknesses in the structure

of the external sector (Table 1). The country had a narrow base of export products; over half

incurring quasi-fiscal deficits, both on account of providing forward cover at subsidized rates to encourage deposit mobilization and also in implementing various concessional lending schemes, the fiscal problems were

compounded by the build-up of FCDs and the ensuing losses on the central bank's balance sheet. See Yaqub, 2003.

-5 -

of the exports were from cotton and cotton-based products. Workers remittances were a sizable proportion of total exports, although they declined in the 1990s and became a somewhat less important source of foreign exchange earnings, but this trend has again reversed in recent years. The sharp fluctuations in these remittances reflected changes in economic, political, and other conditions in the host countries, as well as in Pakistan. The persistent current account deficits had been financed, inter alia, by foreign direct investment

and portfolio capital, but more so by the accumulation of short-term foreign liabilities on account of the FCDs and foreign assistance by bilateral and multilateral donors (Tables 2 and 3).

Under the regulations governing the FCD scheme, the commercial banks were not allowed to use the foreign exchange they received from the FCDs for holding foreign exchange assets, but instead had to surrender it to the State Bank, which provided them with rupees at the prevailing exchange rate. The commercial banks would use the rupees for lending to the private and public sectors, as well as meeting reserve and liquidity requirements. At the same

time, the commercial banks closed their open forex position by purchasing forward cover from the State Bank, which was sold at subsidized rates (the rate of depreciation of the rupee exceeded the cost of forward cover) for almost all years during the operation of the original

scheme. Thus, the FCDs were a highly profitable proposition for the commercial banks, and

they were more interested in mobilizing FCDs than deposits denominated in rupees. The forward cover contract would be for six months, and so long as the deposits remained with

them, the commercial banks would purchase a new contract upon expiry of the old one (see

below).

Besides the opening up of the capital account and its implications for private sector behavior, the FCD scheme had another major implication for macroeconomic stability, because it significantly expanded the capacity of the authorities to obtain reserves through external borrowing. 5 For one thing, the opening up of the capital account made international 
liquidity

a much broader and more relevant concept than international reserves. Instead of relying solely on official international reserve assets for the financing of balance of payments deficits, the authorities could use other available resources such as borrowing those assets from private domestic residents that were close substitutes for international reserves or borrowing from private international capital markets. As noted above, the FCD scheme required that all of the foreign exchange earnings deposited with the commercial banks be

sold to the central bank, which in turn provided foreign exchange cover to the commercial banks. These structural changes to the international liquidity system had made it difficult to derive either simple rules of thumb or rigorous quantitative projections that could serve as meaningful criteria for assessing the need for reserve accumulation.6 Accordingly, the 5 Bartolini and Drazen, 1997.

${ }_{6}$ One could argue that the FCDs did not necessarily make it more difficult to derive rules for prudent reserve

accumulation, because given the set-up in which the SBP provided forward cover to the commercial banks, one

could simply add FCDs to external short-term liabilities and calculate the optimal reserve levels from this metric. However, if one were to use this metric, then it would show that the Pakistan authorities had considered

optimal reserve levels for many years in the period under review to be negative several months of imports of

goods and services, which seems highly unlikely. In fact, the authorities had seen the FCDs not as short-

term

(continued...)

-6 -

discussion below on the need for reserve accumulation, particularly given the large foreign

exchange borrowings, will shy away from constructing quantitative measures of international

liquidity or in comparing reserve holdings with the levels of imports. Instead, greater consideration will be given to an analysis of whether larger stocks of owned reserves would

have improved the performance of the economy.

More generally, external borrowing permits a country to maintain domestic investment at levels beyond those that could be financed through domestic saving alone. If these resources have been channeled into productive capital accumulation, these investments could be expected to generate the stream of returns required to repay the original loans. If the resources were used to sustain consumption, the repayment of the indebtedness must be at

the expense of future levels of consumption, a far more onerous prospect. It is, therefore, of

considerable interest to know whether the increased indebtedness of Pakistan reflected increased investment or increased consumption. The worsening of the current deficit of the 
public sector in the mid-1980s was associated with low levels of total investment in the economy.7 Since the increase in indebtedness reflected an increase in consumption spending

rather than an increase in investment outlays, it is not surprising that Pakistan ran into severe debt-servicing problems and had to seek debt reschedulings.

The external debt situation reached a crisis point in the aftermath of the nuclear tests in 1998,

and the imposition of economic sanctions and the suspension of economic assistance by the

G-8 countries (Table 4).8 As the balance of payments outlook deteriorated sharply and the country faced a large external financing gap, the ESAF/EFF arrangement with the IMF went

off track. In the absence of a program supported by IMF resources, the government decided to "suspend repayment of bilateral debt...... with the continuity of payments to the international financial institutions, it was possible to initiate negotiations with the IMF, which led to the revival of ESAF/EFF arrangement... This was followed by debt relief by the

Paris Club and regularization of bilateral and commercial debt payment arrears.”9 The external debt owed to official creditors was restructured to achieve medium-term debt sustainability, and the approach adopted with regard to the external debt owed to private sector debt was to maintain the face value of the claims and reduce the coupon/interest rate at below market rates.

liabilities, but as a permanent fixture of the financial system, not least because they expected automatic roll-over

of the deposits, particularly those held by the overseas workers. Needless to say, the authorities faced many constraints in hitting the reserve targets but those would not have caused such large deviations from optimal

levels (e.g., from say three months of imports to negative several months of imports).

7 See Hook, 1997.

8 The dollarization of liabilities in the banking system should be seen in relation to Pakistan's external debt, which was not denominated in the domestic currency. If the external debt had been denominated in rupees, it

would have had the important advantage that the debt would have been effectively contingent on aggregate outcomes for the economy. However, since the debt was denominated in foreign currency, the country did not

have the insurance that could have been obtained from foreigner's against events that depreciated the rupee, including when there was a tightening of the external financial constraint.

9 Yaqub, 2003, p. 100.

- 7 -

One way to describe the fiscal and balance of payments problems of Pakistan, and the role

played by the FCDs in exacerbating those problems, would be to say that what had started off

as a "first-generation" balance of payments crisis model, that is, fiscal and current account

imbalances, was transformed into what would be termed the "third generation" model of 
financial crises, reflecting fragilities in the balance sheets of the government, the central bank, and commercial banks.10 In the first generation model, currency crisis is seen in macroeconomic terms, with the main mechanism being the monetization of unsustainable budget deficits leading to reserve losses and the abandonment of an exchange rate peg.11 We have discussed the budget deficits and balance of payments problems in the context of the Pakistan economy in Mirakhor and Zaidi (2004), including an extensive discussion of how the economy came under strain from weaknesses in taxation and public sector expenditures, as well as the impact of the government's debt burden. Although the two main issues confronting the authorities, namely the persistence of widespread poverty and the high level of debt, continue to generate conflicting pressures on the fiscal stance, we are not going to press the point here, since we have argued for it elsewhere. Suffice it to say that while prospects for achieving debt sustainability have improved, Pakistan remains a highly indebted country.12 Furthermore, since poverty is still widespread, the envisaged shift in public expenditure towards increased social and development spending must be implemented

expeditiously, but even with the improved policies, considerable challenges remain in the reduction of poverty and achievement of the Millennium Development Goals.

The "second generation" models take a different tack insofar as a currency crisis is explained

as an endogenous policy decision by the authorities to devalue or not on the basis of their objective function, which balances the benefits and costs of exchange rate realignment.13 The second generation models emphasize that it is not just fundamental weaknesses but also self-fulfilling expectations or sunspot equilibria that are behind many financial crises. In Pakistan, the substantial short-term dollar liabilities in the banking system and the provision of forward cover by the central bank for those liabilities, but without the international reserves to back them up, meant that there were chronic risks of self-fulfilling rollover crises

driven by depositors who might loose confidence and decide to withdraw their funds. Whereas these features could be discussed in terms of the second generation models, it is perhaps more illuminating to discuss them in the context of the balance sheet approach as a product of liquidity and currency mismatches, or what have been called the third generation

models.

10 See Chang and Velasco, 2000, Flood and Marion, 2001 and 2002, and Krugman, 1999.

11 See Krugman, 1979, and Flood and Garber, 1984.

12 We note Pakistan's success in returning to the international capital market through the issuance of a US\$500 million five-year sovereign bond in 2004, which was considerably over-subscribed, and had a broad-based market presence, including European and Far Eastern investors.

13 See Obstfeld, 1994 and 1996. 
- 8 -

The third generation models have the advantage of not only providing policy recommendations for the public sector based on an analysis of its balance sheet, but also in

helping to pinpoint a number of additional vulnerabilities in the corporate and financial sectors. In particular, since financial markets adjust much faster than nonfinancial markets, the onset of a capital account-driven crisis is swifter and deeper than a current accountdriven crisis. Thus, an external current account balance might adjust over several quarters or even years, but an open capital account can adjust in a matter of days. To the extent that the FCD

scheme had led to de facto capital account convertibility even before current account convertibility could be achieved, there was the problem that the rapid adjustments in the capital account would result in overshooting in the exchange markets, which would in turn magnify the impact that financial developments had on the real economy.14 There were many episodes in which nonresident capital inflows would slow down sharply or stop altogether, and residents would exacerbate the "sudden stop" problem by switching from holding domestic assets (such as deposits in local banks) to foreign assets (deposits in banks located abroad).

In the presence of large government borrowing needs, the SBP frequently had no option but to inject liquidity, which mostly resulted in inflation or was sterilized by losses of international reserves.15 There were also a few episodes in which the SBP tried to control the

excess liquidity by resorting to open market operations and increases in interest rates. In addition, in the face of sustained foreign exchange market pressures and the desire to preserve the level of international reserves, the SBP had allowed the rupee to depreciate gradually most of the times. However, as discussed extensively in the context of the Caballero-Krishnamurthy model below, there were occasions when there was resistance to

exchange rate flexibility. As a result, the exchange market pressures would build up, and the

SBP would eventually resort to discrete exchange rate adjustments. The exchange rate depreciation worsened the public finances owing to the higher domestic cost of debt service, and as discussed extensively elsewhere in the paper, the SBP's balance sheet was adversely affected by the depreciation, because it provided foreign exchange cover to the commercial

banks. 14 See Yaqub, 2003. 
15 The sharp increase in capital inflows following the introduction of the FCD scheme was initially seen as a

welcome development, and although there were some concerns regarding possible adverse effects on inflationary pressures and exchange rate overvaluation, these concerns were largely set aside as the FCDs were

not seen as imposing a serious constraint on the conduct of financial policies. However, the large buildup of FCDs based on workers' remittances and other inflows was not an "endogenous effect or a pull” of resources

into Pakistan to satisfy a large unmet demand for investment financing. The inflow was more of an "exogenous

event or a push" that resulted from the sharp increase in Pakistani workers in the gulf and other oil exporting

countries in the Middle East in the wake of the oil boom. This point is worth elaborating in terms of asking the

hypothetical question of what happens to investment when there are restrictions on capital inflows. There

are

two polor scenarios: (1) when physical investment is constrained by the availability of domestic saving, then a

relaxation of the capital account restrictions would allow higher domestic investment. (2) If domestic investment is not constrained by saving, or alternatively and this was the case in Pakistan, if the foreign savings

are pre-empted and used for public sector consumption, then integration with the international capital markets

would not lead to higher levels of domestic investment. The question that did the increase in foreign capital served to finance investment or was it really financing consumption is discussed in Mirakhor and Zaidi, 2004.

- 9 -

Given the provision of forward cover by the SBP, the commercial banks did not have an open foreign exchange position, but they did have to face the problem of their borrower's solvency following a depreciation. The Pakistan experience with regard to the balance sheets

of banks was different from those in the Asian financial crisis in which private corporations, especially in Indonesia and Thailand, found themselves suddenly insolvent. In those Asian countries, even though many bank loans were hedged on paper, the corporate defaults on domestic dollar-denominated loans left the banks unable to cover their dollar deposits. Ultimately, external overborrowing and currency risk shifted from the corporate sector to banks (which faced loan defaults) and then to the government (sharing in the recapitalization

of now-insolvent banks). In Pakistan, the currency risk was borne by the central bank, but there was still the problem of corporate defaults insofar as a large currency depreciation sometimes led to increases in borrowing costs and/or credit rationing, which would hurt the performance of the firms much more than any gains from increases in the own product price.

For public enterprises, whose output prices were rigid, the costs rose following the depreciation but the revenues did not rise concomitantly. This explains why there was resistance to exchange rate depreciation among various groups, even when the depreciation was simply to preserve the real exchange rate in the face of inflation. The reason for 
mentioning this point is not to deny the efficacy of the exchange rate as a tool for macroeconomic adjustment, but rather to point out the complexities involved and the constraints imposed by the FCD scheme on the conduct of monetary and exchange rate policies in Pakistan.

Moreover, even for private enterprises, whose output prices were flexible and borrowing was

mostly in domestic currency, there was still resistance to a more active exchange rate policy

because of the reliance on short-term borrowing and the need for periodic refinancing by the

firms. This problem may be attributed at least in part to the FCD scheme, because even when

there was access to international capital markets, there was the need for periodic refinancing

of the borrowing undertaken by the authorities to finance international reserve holdings, and

the costs of such financing had exhibited marked volatility. Since the authorities had kept reserve holdings to unduly low levels because of cost considerations, the result was that the

country had become vulnerable to shocks that adversely affected the balance of payments positions. The authorities could have held down the risk premium the country had to pay on

its external borrowing by pursuing appropriate macroeconomic policies and strengthening the external current account position. This would have led to an increase in the proportion of owned reserves, which would have reduced the country's vulnerability to abrupt changes in

the availability of borrowed reserves. Unfortunately, since the authorities could not always rely upon private markets to extend borrowed reserves, the high and volatile risk premium and/or credit rationing in external borrowing had a severe adverse effect on the domestic financial market. These external disturbances would be translated into high and variable domestic borrowing costs, and some firms would face credit rationing, even though they had to refinance their short-term loans.

- 10 -

\section{Foreign CurRency Deposits AND the Constraints on FinANCIAL Policies}

\section{A. FCD Scheme and International Reserves}

The way in which the FCD scheme was implemented (see Box 1 for a brief discussion of the

evolution and technical details of the FCD scheme) meant that it was a major step in the liberalization of the capital account. It not only liberalized the capital account insofar as it allowed nonresidents (e.g., Pakistani's residing abroad) to make deposits in the domestic banking system and then use these deposits freely for various kinds of capital account transactions, which were previously restricted, but it also meant an opening up of the 
capital

account even for the residents who had FCD deposits. It might appear puzzling as to how the

transactions between two residents (resident depositors and domestic banks) can translate into a capital account issue, but it can be explained in terms of the highly restrictive exchange

and payments regime before the introduction of the resident FCD scheme. Foreign exchange

was almost a forbidden word in the years before the FCDs, as exchange controls loomed large in the minds of anyone; even one who needed foreign exchange for a private visit

abroad for medical treatment or educational purposes had to face several bureaucratic and other hurdles. However, as the FCDs grew rapidly, the government deregulated the stringent

foreign exchange regime, and this was a great benefit for both the bankers and the public at

large; resident Pakistanis were allowed to open and maintain foreign currency accounts, and

they could use those funds for most international trade and financial dealings, current account

as well as capital account transactions.

Some of the biggest beneficiaries of the FCD scheme and the foreign exchange deregulations

were residents who could now deposit in the domestic banking system their savings and have

a hedge against any depreciation of the rupee. At the same time, these accounts also greatly

facilitated the making of direct payments outside of the country, thereby avoiding the cumbersome procedures involved in documenting and obtaining permission for external remittances in the previous foreign exchange regime (international travelers, students in overseas colleges and medical patients going for treatment abroad were prime beneficiaries).

Moreover, in contrast to the previous stringent exchange controls, residents could buy foreign

exchange from authorized dealers or even from the kerb market, and then deposit the funds

into FCD accounts, and in sharp contrast to the previous exchange and control regime, use

those accounts for capital account transactions.

The FCD scheme had not only led to the premature liberalization of the capital account and

the dollarization of the economy, it had also led to the segmentation of the foreign

exchange

market, mainly in terms of diverting home remittances from the official to the moneychangers

market. The FCD scheme also created several well-connected special interest groups who profited from the multiple exchange rate regime and opposed the various 
proposals for exchange reforms.16 Besides the provision of forward cover by the SBP at ${ }_{16}$ For example, residents could use the dollars from the FCDs to buy Foreign Exchange Bearer Certificates (FEBC) that were traded on the stock market, and since the implicit exchange rates on these instruments would

frequently diverge from the official rates, this would result in multiple currency practices.

- 11 -

\section{Box 1. Evolution of FCDs}

A notable characteristic of Pakistan's financial system during the period since the mid-1970s has been the large increase in Foreign Currency Deposits (FCD) in the banking system. Foreign currency accounts were introduced in 1973 with a view to providing a savings instrument in the domestic banking system that would be attractive for the sizable and growing population of Pakistanis working abroad, but there was also the motivation mentioned earlier to increase the foreign saving available to finance government deficits. Initially, these deposits were transfers from abroad, mainly workers remittances, but the FCD scheme proved to be perhaps even more attractive than had been originally intended, and these deposits grew rapidly. In particular, when residents were allowed to hold FCDs in 1991, the scheme acquired a new dimension in terms of a major opening up of the capital account of the balance of payments. These liberalization measures led to increasing dollarization, because the high and variable rates of inflation and exchange rate depreciation, together with the limited flexibility in rates of return on bank deposits denominated in rupees, made foreign-currency- denominated assets more attractive as stores of value. Residents were finding that the returns on foreign currency denominated deposits, after adjusting for the exchange rate depreciation, were often higher than those available on rupee assets, not least because the relative attractiveness of FCDs was exaggerated by tax advantages plus better terms given by banks because of the forward cover provided by the SBP. Furthermore, the foreign-currency-denominated assets were perceived to be less risky because of lower fluctuations in the real rates of return and also in terms of possible changes in the taxes on financial assets; taxes on rupee assets had been changed on a few occasions, whereas foreign currency deposits had remained tax free since their inception. Whether one looks at absolute figures for FCDs, or per annum growth rates, or any other commonly used measure for the performance and attractiveness of an asset, it is clear that FCDs grew very rapidly. Foreign currency deposits grew from US\$26 million in 1975/76 (the first full year of their operation) to a peak of US\$10 billion in 1998 (excluding institutional deposits). The per annum growth rates were almost always in the double digit levels and on occasions in the high double digit levels such as in 1985/86 when the growth was 83 percent or 1991/92 when it was 43 percent. While these growth rates and absolute figures are large, they are even more striking when they are expressed as a proportion of foreign exchange reserves and trade flows. FCDs represented 558 percent of foreign exchange reserves in 1997/1998. As a proportion of imports, FCDs amounted to 94 percent in 1997/98. In addition, the dollarization ratio - the ratio of resident foreign currency deposits to broad money inclusive of foreign currency deposits—-had risen sharply to reach 23 percent in 1997/98.17

From the inception of foreign currency deposits in Pakistan in January 1973 till June 1992, the State Bank had provided forward cover to the financial institutions without charging any fee for the service. However, as the foreign currency deposits increased rapidly and the rupee depreciated against the major currencies during the second half of the 1980s, the losses incurred by the State Bank from its forward cover operations increased substantially. To offset those losses, it was decided to introduce a forward cover fee effective from July 1, 1992. Initially, the forward cover fee was set at the rate of 3 percent per annum on U.S. dollar deposits, but there were only a few minor upward revisions to that fee, which were not enough to cover the cost.18 A major constraint was that since sharp changes in the forward cover premium fee could possibly lead to large movements in FCDs, particularly the institutional funds mobilized by the banks. Accordingly, the forward cover fee was almost never adjusted when there would be changes in expectations of rupee depreciation, with the only exception being the minor changes in the second-half of the 1990s.

The provision of forward cover by the State Bank to the commercial banks on their FCDs had tended to lower central bank's profits, because the charges on the provision of forward cover had been less than the losses from rupee depreciation, except for 1994/95 when there was a small net profit. For example, in 1993/94 and 1995/96, the net losses from forward cover operations were in excess of Rs. 13 billion, which meant lower SBP profits and nontax revenues. The root cause for these losses was that there was a quasi-fiscal motive behind the provision of forward cover for FCDs. 
- 12 -

subsidized rates, the FCDs were exempted from taxation, and depositors were protected from

official inquiries about the sources of income for their deposits, which was of "value" to at

least some depositors because of the problems with tax evasion in the country. In addition,

FCDs were a highly liquid savings instrument because of the unrestricted withdrawal facilities, which greatly facilitated international transactions in both the current and capital accounts. As stressed in Yaqub (2003), the removal of many of the features of the FCD scheme, which were behind the market distortions, if not the dismantling of the scheme itself, was vital for the reform of the exchange market, but the dependence of the country on the scheme to finance persistent current account deficits had greatly complicated that task. "The benefit of the scheme to the government was that it had access to foreign exchange that could otherwise be tucked away in accounts in foreign countries or under the rug within the country. The successive governments found it a convenient source of financing the rising current account deficit, and thereby postponing difficult policy measures to address the fundamental disequilibrium in the balance of payments."19

The provision of forward cover for FCD deposits at subsidized rates by the SBP, and indeed

the way in which the rates of return on these deposits were calculated by the commercial banks, were in many respects inconsistent with the official policy of Islamic banking, which

was introduced in 1985. The key requirement of Islamic banking is the replacement of interest-based financial instruments with others that operate on the basis of risk and profit sharing.20 Iqbal and Mirakhor (1987) discuss how the Islamization process in Pakistan was undertaken in phases: the asset side of the banking system apparently has been much slower than the liability side in converting to Islamic modes of finance. The FCDs did not have any

close linkages with the real rates of return in the economy at large, nor with the profitability

17 It should be noted that the estimates of dollarization in the Pakistan economy that are discussed are biased

downward. Since data on foreign exchange deposited abroad and foreign cash held by residents are not available, the estimates of dollarization are based on domestic foreign currency deposits only, which greatly underestimate the dollarization phenomenon. For one thing, the currency-to-deposit ratio in Pakistan is very high in comparison to other countries, which can be explained in terms of the high inflation rate but also the

high transactions costs in the banking system, notably the delays in the provision of banking services, as well as

a general lack of confidence in the banks given the well-known high administrative costs and large 
nonperforming assets of the major banks. For the same reasons, one would expect that there are significant holdings of foreign cash in the country, and the data reported in this paper should be interpreted as providing a

lower bound for estimates of dollarization.

18 In setting the forward cover fee, the State Bank would target a profit margin for banks on foreign currency

deposits of about 2 percent, taking into account likely developments in domestic lending rates and international

deposit rates. Since domestic and international interest rates often exhibited sharp fluctuations over relatively

short periods, there were periods when the calculated profit margins differed significantly from the 2 percent

target.

19 Yaqub, 2003, p. 98.

20 See, for example, Iqbal and Mirakhor, 1987, and Mirakhor, 1988. Although interest rate controls were discontinued with the introduction of Islamic banking, which had the effect of making the cost of borrowing more flexible, but the guidelines for calculating profit rates to pay on even domestic currency deposits continued to constrain flexibility because they could only be adjusted once every six months.

-13 -

of the individual banks. The depositors in the FCD scheme were receiving returns denominated in foreign currency, whereas the banks were holding their assets in rupees, and

the foreign exchange risk was borne by the SBP. Put it differently, the banks in effect had dollar assets because the SBP was providing the forward cover, and the SBP had the exchange risk. The high returns on FCDs reflected in part the banks passing on some of the subsidies to depositors.

Since the SBP ran up huge losses in providing this foreign exchange cover to the commercial

banks, there was effectively a wedge between the return on the assets and liabilities side of

the banks' balance sheets. In contrast, the transformation of banking from an interestbased

system to one that relies on profit sharing makes Islamic banking system an essentially equity-based system, and the returns on bank deposits cannot be determined ex ante. Moreover, it should be stressed that an Islamic financial system has a number of features that

distinguish it from the interest-based system, and the absence of a fixed or predetermined interest rate is only one such feature. Indeed, one of the most important characteristic of an

Islamic financial system is that there is a close link between the real sector and the financial

sector, and FCDs are not the natural instrument for strengthening such linkages. By contrast, there are several other alternatives that could serve this purpose better, including denominating private debt in terms of nontradable goods, or alternatively, GDP-indexed financial instruments, which we discuss in Section IV of this paper.21

The State Bank had advanced proposals in the mid-1990s to address the FCD problem, but 
these attempts did not go very far and were attacked from many sides. Much of the criticism

was not surprising. Commercial bankers, for instance, were not keen to give up their lucrative business dealings in FCDs, particularly as regards the holding of counterpart funds to these deposits in high yielding domestic public debt, with the central bank absorbing the

exchange rate risks. Meanwhile, depositors wanted hedges against high inflation, and found the FCDs to be a convenient means for protecting their savings. Above all else, whereas the officials in the Ministry of Finance were concerned about the losses on account of forward cover operations by the central bank, they were not willing to acknowledge how the FCD scheme came into being in the first place to plug the holes in the balance of payments accounts, attributed in no small part to the fiscal imbalances. In short, the various sectors of

the government were unwilling to take the bold steps needed to sharply reduce the budget deficits, and build up the international reserves to be used as a cushion for weathering the portfolio shifts that would have invariably occurred if major changes were to be effected in

the implementation of the FCD scheme. Indeed, the opposition from the various quarters was

such that the SBP would end up pushing modified proposals with the hope that perhaps at least a diluted version of the original proposal would be accepted. Unfortunately, these latter steps proved to be a tall task as well, and suggestions such as simply raising the forward cover fee on the FCD deposits to eliminate the losses on those operations were greeted with considerable skepticism, and required major efforts from SBP management to gain their acceptance.

21 See Chamon, 2001, for the case of denominating private foreign debt in terms of a nontraded good, and Borensztein and Mauro, 2002, for the case of GDP-indexed bonds.

- 14 -

\section{B. Borrowed International Reserves Versus Current Account Adjustment}

The economy had been experiencing a slowdown in activity and mounting debt-servicing difficulties since the early-1990s, and the potential for disorderly bank runs and capital flight

had been a looming danger for some time. After the nuclear tests of May 1998 and the international economic sanctions, the government decided that it had no choice but to abandon the convertibility of foreign currency deposits to avoid a financial panic. While this action lifted a huge burden off the economy, it also created a policy credibility problem. Unfortunately, the "Government did not take the public into confidence by explaining the implications for the economy of the alternative of keeping open the window for the withdrawal of foreign currency deposits in the context of meager foreign exchange reserves 
and heightened economic uncertainty...There was a strong public to the decision on foreign

currency deposits...”22 International reserves were only a small portion of total FCDs and even a modest run on reserves would have led to the depletion of the total reserve stock and a collapsing exchange rate. The short-term liabilities in the form of FCDs were a multiple of

the reserve holdings, which meant that the incentive to run, hedge and cover currency risk were massive under the international economic sanctions. Most observers took the view that there would inevitably be speculative attacks on the rupee. While the costs of shorting the rupee had been made high and could have been made higher still by further spikes in the interest rate, it was decided that this might not prevent a run on the reserves (if capital controls and a freeze on FCDs were not imposed) as the expected benefits of covering currency positions were higher than any sustainable short-term interest rate.

The point that Pakistan should have had large holdings of unborrowed international reserves

is supported by numerous studies on reserves and adjustment. The demand for international

liquidity is a function of the scale and variability of the transactions, which flow through a

country's foreign exchange market, including the level of imports of goods and services, size

of external debt-servicing, fluctuations in export proceeds, etc. For example, econometric estimation of demand for liquidity functions suggest that those countries that tend to have, among other things, larger variations in export earnings and greater external debt servicing burdens should have relatively larger international liquidity-GDP ratios. These and other results, which are not mentioned for the sake of brevity, would suggest that Pakistan should have held sizable international reserves, but that was not the policy pursued by the authorities. Furthermore, not only did the country not meet this demand for relatively higher international liquidity, but even its limited international reserve holdings were acquired through external borrowing. These borrowed reserves as opposed to owned reserves created

the twin problems of the expensive cost of external borrowing relative to the return earned on holdings of reserve assets, as well as the limited ability to supplement the reserve holdings in times of need through private borrowing.23 22 Yaqub (2003), page 100.

23 Industrial countries can count on the availability of private lines of credit at all times and have found borrowed reserves to be an efficient and reliable source of international liquidity. However, Pakistan did not

have the same potential to borrow from private sources to finance temporary balance of payments deficits 
at all

times; even when it did have access to international capital markets, there was the problem that the country would find that when it approached the private sources for international liquidity in times of need, it ended up

(continued...)

- 15 -

Several prominent economists have advanced proposals that additional measures are required

to augment the capacity of governments in emerging markets to reduce these countries'

exposure to capital account crises. Among the self-protection policies, Greenspan (1999)

has

suggested that it might be prudent for countries to hold foreign currency reserves in the

amount of total external debt maturing within one year. This proposal revises the

traditional

rule of thumb that foreign reserves should cover three to four months of imports to a rule

based on short-term debt amortization. If the Pakistani authorities were to have adopted

this

proposal, then in the 1990s, they would have been keeping international reserves at levels which would have been several times the actual levels for most years. This gives some indication of the severity of the problem, and while we present the details below, at this juncture, it might be sufficient to say that just the costs of holding those reserves in terms of

interest rates on borrowed reserves or import compression to acquire unborrowed reserves

would have been of the order of several hundred million dollars.

Another recommendation that is often included in the self-protection policies is for countries

to arrange contingent lines of credit, which would effectively mean the purchase of an option

to borrow reserves if and when needed to avoid illiquidity during a crisis. While this proposal

raises the interesting question of whether these lines of credit should be arranged with private

creditors or should be provided by the international financial institutions, in the present context of the underinsurance problem in Pakistan, it helps to clarify the point that the FCD

scheme had embedded in it huge hidden costs that were not immediately apparent.24 We mention this option to suggest that if one were to approximate the costs of purchasing such

an option in the financial markets, they would have been seen to be an unbearable burden on

the budget. Needless to say, we are not necessarily recommending that the authorities should

have purchased insurance in the international capital markets to close the open foreign exchange position on account of the FCDs, because this proposal would have to be evaluated

in relation to the costs of other policies that could have served the same purpose, 
including

policies that would have reduced the reliance on FCDs for savings mobilization (e.g., fiscal

and monetary policies aimed at low inflation and exchange rate stability, which would have

made financial instruments denominated in domestic currency more attractive to savers). Putting aside for the moment the issue of credit rationing in international capital markets and

calculating the net carrying costs of reserves for the country by focusing only on the difference between its cost of acquiring reserves and the yield on its reserve assets, one finds

that even under this scenario the costs for Pakistan were high. For the industrial countries, borrowing from private international capital markets is a low-cost and flexible source of international reserves, and the net cost of borrowed reserves for these countries when it is measured as the difference between the loan interest rate and the yield obtained on reserve

signaling the balance of payments difficulties, which resulted in sharply higher borrowing costs. This supports

the conventional wisdom that the ratios of reserves to imports for the developing countries should generally be

higher than those for the industrial countries.

24 See Caballero, 2003.

- 16 -

assets is almost negligible. In recent years, the net interest cost of holding reserves for industrial countries have been estimated to have averaged less than 1 percent per annum.

In

contrast, the average carrying cost of foreign exchange reserves for Pakistan in terms of the

difference between the weighted average yield on the syndicated loans and the average rate

of return on the reserve assets has been substantial. This is because the cost of lending to Pakistan, like other developing countries, is based on a formula, with the cost of funds to the

borrower comprising the market interest rate--generally represented by the LIBOR or the U.S. prime rate-plus a margin or spread. The interest rate fluctuates over the maturity of the

loan and the spreads over LIBOR vary according to the perceived risks associated with lending to a particular country as well as with the degree of liquidity in international capital

markets. The LIBOR itself can be regarded as consisting of a "risk-free" interest rate, which

could be represented by the U.S. treasury bill rate and an additional margin or banking spread

which reflects both the cost of bank intermediation and the risk premiums that banks have to

pay in funding their own lending. This banking spread has varied considerably over time and 
is significantly influenced by financial developments in industrial countries. Since the probability of running into debt service difficulties is increased with higher interest rates in

the international capital markets, the banking spread tends to rise to reflect this increase risk.

Pakistan's cost of external borrowing has fluctuated sharply, and for some years has been well into the double digit levels.

Lenders to Pakistan have also resorted to structured finance or collateralization to shift the

financing risk to the country. One technique to mitigate transfer and exchange rate risks has

been to establish escrow accounts and to use future export receivables as collateral for the commercial loan (for example, the receivables from Pakistan Telekom were used in one such

transaction). As is well known, however, these techniques may have negative macroeconomic implications if pursued too vigorously or if risk-sharing attributes are skewed too heavily against the borrowing country. The earmarking of foreign exchange revenues for particular creditors may reduce the country's flexibility in responding to a balance of payments crisis. Such contracts may also set prices at significantly below market

levels. All this would suggest that the interest rate on a commercial bank loan does not fully

reflect the cost of holding reserves when Pakistan had borrowed in international capital markets.

\section{FCDs and the Costs of Accumulating Reserves}

The above discussion has stressed that to accumulate reserves through external borrowing,

Pakistan incurred significant interest costs because of the spreads between borrowing rates

and the rates of return on reserve assets. On the other hand, if reserves were to be accumulated through the compression of domestic demand and net imports, then the country would incur even greater costs in terms of foregone consumption or investment. The reason why it is optimal to pay those costs is that there are benefits from holding reserves. The alternative of not doing so would be to accept greater vulnerability to abrupt changes in the

availability of external borrowing and in undertaking rapid import compressions and current account adjustments. However, those costs cannot be saved if the reserve holding are augmented through foreign currency deposits.

-17 -

While FCDs provided additional foreign exchange inflow, they did not constitute resources that were available on net terms, e.g., to defend the rupee against a speculative attack. At first 
glance, it might seem that cost savings accrue when reserves are acquired through FCDs rather than through external borrowings, because there appears to be a wedge between the interest cost of external borrowing and the cost of providing forward cover for those FCDs

throughout most of the sample period. In this sense, reserve accumulation through the mobilization of FCDs can be said to provide resource gains for the country.

Unfortunately, the lower cost of adding to reserves via FCDs mobilization are more apparent than real. These costs are understated because the continued build-up of the deposits meant that the SBP had to provide the foreign exchange cover. In other words, the costs were hidden in terms of the open foreign exchange position of the SBP. Furthermore, the simple analysis that only takes into account the cost of the FCDs overlooks the possibility of an offsetting increase in the cost of external borrowing from other private sources. In particular, it should be noted that the interest rate that a country is charged in private financial markets on a sovereign loan reflects the perceptions of market participants regarding the riskiness of lending to that country as well as to the specific borrower. Furthermore, if private creditors were to adopt the view that Pakistan would service its foreign exchange obligations to the depositors in the banking system with greater priority than its obligations to other private markets, then a significant increase in FCDs would lead private creditors to believe that the

likelihood of repayment of their claims had been reduced. Consequently, the risk premium charged on borrowing from private credit markets would rise if the total risks associated with

lending to the country was perceived to have risen and any savings from FCDs would be offset by the higher costs of borrowed reserves.

\section{FCDs, Underinsurance, and International Collateral}

This section provides a perspective on the problems of FCDs and the lack of international reserve holdings in terms of the dual liquidity model developed by Caballero and Krishnamurthy.25 The dual-liquidity model focuses on the financial constraints affecting borrowing and lending among agents within the domestic economy, which are quite distinct from those affecting borrowing from foreign lenders. In particular, the analysis sheds light on

how the wrong incentives from the FCD scheme affected the behavior of firms and banks, and led to the underinsurance problem, whereas the authorities were doing the opposite of what would have been considered an appropriate policy for international liquidity management.

In the Caballero-Krishnamurthy model, international liquidity constraint is defined as that situation in which domestic agents have sufficient collateral to borrow from other domestic agents, but cannot borrow from foreigners because the country has a shortage of international 
collateral. The model assumes that when a firm experiences a negative shock, it first borrows

against its net international collateral from foreigners, and finances the remaining

financing

needs from other domestic firms that did not receive the shock. The analysis helps to

show

how the presence of financial constraints causes domestic firms to undervalue the social

${ }_{25}$ Caballero and Krishnamurthy, 2001, 2003, and 2004.

- 18 -

benefit of borrowing in the local currency, which has several interesting results

implications

for exchange market pressures and the conduct of monetary policy.

In what Caballero and Krishnamurthy have dubbed the vertical framework, international

reserves are an important component of liquidity, because here the supply of international liquidity is inelastic, with foreign investors unwilling to provide additional funds and domestic agents resorting to hoarding whatever little they have of international liquidity.

In

this connection, Caballero and Krishnamurthy recommend that central banks should accumulate international reserves during capital inflow booms and reverse them during external crises. With regards to monetary policy, it would appear that most central banks have loss functions that aim at finding the right trade-off between the losses from output variability against the benefits of maintaining an inflation target. In the vertical framework, a central bank will see no output stabilization benefits from pursuing an expansionary monetary policy and only inflation-target losses, and therefore will not conduct a countercyclical policy in the crisis situation (see Appendix I). However, the cost of not pursuing the countercyclical monetary policy is that the private sector will underinsure against such events. It is this problem of the private sector tending to underinsure against an

external crisis by over-borrowing that leads to the authors' suggestion that the government

and the central bank will have to take precautionary measures, including taxes on capital flows and building up international reserves.

Caballero and Krishnamurthy's analysis provides insights into the constraints faced by the policymakers in Pakistan, and in particular, their vertical framework forms the basis for an

analysis, which is geared towards formulating prescriptions for optimal policies. An important insight from this analysis is that the private sector tends to underinsure against external crisis. The private sector borrows too much dollar debt, thereby making the country less liquid in the international market than is socially optimal.

We have discussed the dual liquidity model in Appendix I in detail to show how the private

sector underinsurance problem was aggravated by the policy of encouraging the mobilization

of FCDs in Pakistan. One important policy implication of this model is that since the private 
sector on its own carries too little international liquidity, the central bank should attempt to

attenuate this problem by carrying additional international liquidity in the place of the private

sector. In particular, since financial constraints cause domestic firms to undervalue the social

cost of borrowing in the foreign currency, the authorities should take measures to mitigate the underinsurance problem by proactively managing international reserves. Unfortunately, the Pakistani authorities did not proactively manage the international reserves, attributed mainly to the persistent fiscal deficits. Also, the way in which the FCDs were mobilized (e.g., the preferential tax treatment on these deposits and the provision of forward cover for these deposits at subsidized rates) led to an excessive growth of these short-term foreign liabilities.

The sharp increase in FCDs had destabilizing effects on domestic borrowing costs, international reserves management, and more generally on monetary policy. A shift from FCDs into foreign cash or capital outflow would create a shortage of liquidity in the domestic

banking system and raise the cost of borrowing in the economy. To be sure, a drawdown of

domestic currency deposits into foreign exchange would have a similar effect, but the point is

-19 -

that these vulnerabilities were created by the relaxation of capital controls on account of the

FCD scheme. This shift would also create foreign exchange market pressure, and lead either

to a drawdown of international reserves or rupee depreciation. Since FCDs made it easier to

transfer funds abroad, or to substitute foreign cash for savings held in the banking system, in

the event of a shortage of foreign exchange, the difficulties would be compounded because at

the very time when the country would want to husband its foreign exchange resources, there

might be leakages of foreign exchange from the banking system. Thus, when there was a balance of payments crisis, owners of resident and nonresident foreign currency accounts would be concerned about country risk, and they would convert their holdings into foreign cash or shift them abroad, which would accelerate the depletion of international reserves.

\section{E. Implications of FCDs for Financial Policies}

The major advantage of having foreign currency deposits is that they provide residents with a 
reliable store of value in periods of high inflation and currency depreciation, which helps to

avoid the problems of low domestic savings when rates of return are low or highly variable.

However, this has to be balanced against the major disadvantage of posing formidable challenges to the policymakers in terms of hindering monetary control and exchange rate management in an environment of low international reserve holdings, as well as causing quasi-fiscal losses and the erosion of the tax base. In weighing the benefits from large foreign

currency deposits against the costs, it would appear that these deposits had grown so large

under the original scheme that the benefits were being swamped by the costs. FCDs could have helped to build up international reserves or to allow foreign savings to finance investment, but unfortunately these benefits did not materialize.

Furthermore, the large volume of foreign currency deposits, the specific institutional characteristics of those deposits, especially under the original scheme, and the changing share of FCDs in total money supply had constrained the conduct of monetary, fiscal, and exchange rate policies in a number of ways. Monetary policy was affected because FCDs permitted greater substitutability between domestic and foreign assets, as well as by effecting changes in the transmission mechanism of monetary policy. The principal channels through which fiscal policy was affected were the erosion of the tax base, lowering of nontax revenues, and limitations on seigniorage revenues from a given inflation target. Exchange rate policy was constrained by losses from the forward cover operations on FCDs, and by concerns about possible perverse international capital flows and self-fulfilling expectations regarding a foreign exchange shortage.

\section{Monetary Policy}

One constraint on the conduct of monetary policy related to the implications that the FCDs

had for the money supply process, including difficulties in the implementation of the reserve money management program. The large and changing share of FCDs in the money supply

had altered the behavioral relations between reserve money (operational target), broad money (intermediate target), and the ultimate objective of controlling inflation. The State Bank, which conducted its open market operations to achieve a reserve money target that would also achieve its intermediate target of broad money, found achieving its inflation objectives

- 20 more difficult. In particular, the dollarization process had lowered the demand for domestic cash balances. Furthermore, the achievement of the reserve money target was itself 
constrained by the movements of foreign capital, because reserve money demand had become more sensitive to monetary policy's effects on domestic rates of returns.

Yet another constraint on monetary policy was that when the SBP sought to defend the rupee

by increasing the return on domestic currency assets, this also increased the cost of funding

for banks, and if the policy were pursued with sufficient vigor, some banks would have had

to contract their portfolios by calling in their loans. However, there was the concern that if

borrowers were unable to repay immediately, not least because much of the short-term lending by banks was for "rollover loans," then that might set in motion the beginnings of a

banking crisis. On the other hand, if the SBP did not defend the exchange rate but allowed it

to float more freely, then there was not only the problem of the large public sector foreigncurrency-

denominated debt, but also the issue that some firms might get caught in the currency mismatches. Moreover, as if these were not enough constraints on the conduct of

monetary policy, there was the problem of the losses on the SBP's own balance sheet from exchange rate depreciation, which we discussed earlier in the context of the provision of forward cover for the FCDs by the SBP.

\section{Fiscal Policy}

With regard to fiscal policy, FCDs had adversely affected the mobilization of both tax and

nontax revenues. In the case of nontax revenues, the provision of forward cover by the SBP

to the commercial banks on their FCDs resulted in lower central bank's profits, because the

charges on the provision of forward cover had been less than the losses from rupee depreciation, except for 1994/95. In the case of tax revenues, FCDs had eroded the tax base

for financial assets because unlike the income from domestic currency denominated assets,

FCDs were exempt from all taxes. Since there had been a steady substitution of FCDs for domestic currency denominated assets in the portfolios of residents over the years, the tax base in the financial sector was lower than what it would have been otherwise, and this meant

that the inflationary consequences of a given fiscal deficit were more severe.

Turning to external debt issues, the large build-up of foreign currency deposits created both a "destabilizing” and debt servicing burden for the country.26 As is the case with other forms of

${ }_{26}$ Experience in many developing countries suggests an upper bound on the potential magnitude and sustainability of short-term capital inflows. A key factor that influences the sustainability of those inflows 
is the

degree to which external resources add to overall investment in the economy and whether the profitability of

those investments is higher than the cost of external borrowing. Furthermore, the form of the capital inflow-

foreign direct investment, portfolio capital, or short-term bank lending — has a bearing on the sustainability of capital inflows. Regarding sustainability, two points need to be stressed about the FCDs in Pakistan. First, it

would be a case of mismanagement of maturities if Pakistan were to incur short-term financial liabilities to finance long-term investments in physical capital. Second, foreign capital inflows such as nonresident FCDs

can substitute for domestic savings, and the data for Pakistan show that at least a part of the foreign savings was

used to finance consumption and not physical investment. See Golsbrough and Zaidi, 1986; Hook, 1997; Mirakhor and Montiel, 1987; and Mirakhor and Zaidi, 2004.

- 21 -

short-term capital inflows, foreign currency deposits held by nonresidents not only caused

the stock of foreign debt to increase relative to GDP but also created additional difficulties in

terms of the need to rollover maturing deposits on a continuing basis. The average interest

rate on foreign currency deposits was more than twice that on Pakistan's medium- and long-term debt towards the end of the original FCD scheme. With the volume of such debt

being about double that of short-term deposits, debt servicing on foreign currency deposits was of the same magnitude as on medium- and long-term foreign debt.

\section{Exchange Rate Policy}

One way in which exchange rate policy was affected by FCDs was in terms of the risks arising from perverse international capital flows. Although there are many determinants of international capital flows, and indeed many channels through which even just one of those determinants, that is, exchange rate, affects the inflow of capital, it is generally assumed that an exchange rate depreciation would lead to capital inflows. In the simple model in which domestic and foreign assets are gross substitutes and agents keep relatively fixed shares of

the various assets, a currency depreciation would lead to capital inflows, because the share of foreign assets would be increased by the currency depreciation. However, when substantial

foreign-currency-denominated assets are held by residents in the domestic banking system, the currency depreciation lowers the share in portfolios of assets denominated in domestic currency, but that share need not be restored through an inflow of foreign capital but 
could be

done by a substitution from FCDs into domestic assets. In this situation, since there is no need for an inflow of foreign capital for portfolio reallocation purposes, one important channel for foreign exchange reserve accumulation through an exchange rate depreciation is essentially blocked.

\section{FCDS AND THE USE OF NATIONAL SAVINGS FOR DOMESTIC INVESTMENT} A. Recent Increase in International Reserves and External Borrowing Before turning to a discussion of recommendations for fixing the FCD scheme and its related policies, we first discuss a striking recent development and one which is totally at odds with the experience of the past two decades, namely, the substantial increase in the foreign exchange reserves during 2001-04. Since the country embarked on the most recent economic adjustment program, its foreign exchange reserves have increased from less than a billion dollars (few weeks' worth of imports) to more than US\$12 billion. This is a historical high

not only in nominal terms, but more importantly in relation to imports and short-term foreign liabilities. Clearly, Pakistan is better placed now than before to withstand external shocks, such as sharp increases in international interest rates and oil prices. Indeed, the authorities have indicated that reserves have reached such a comfortable level that they are in a position

to repay in advance of maturity some of the more expensive external debt. In this connection, we would like to suggest that this might be an appropriate time to give consideration to the

possibility of issuing some innovative debt instruments. In other words, as steps are taken to

retire some of the more costly debt, and even though there would be retirement of debt on a

net basis, there might still be some scope for direct substitution of new instruments for the

old debt. At the same time, we would like to put in a word of caution and reiterate the point -22 -

noted above regarding the difficulties involved in trying to identify a prudent level of reserves. This is not to deny that if the costs of holding reserves are too high, then it is reasonable to think about the alternative paths that would lead to a lowering of reserves. There may well be a strong argument for Pakistan to use its reserves to repay some of its costly external debt, but the Pakistan economy is subjected to significant shocks that are associated with agriculture, and concomitant with the recent reserve accumulation has been the massive increase in FCDs, albeit not under the original scheme but the new scheme (the 
data in tables 2 and 3 are for the original scheme). Furthermore, while it is to be recognized

that official debt rescheduling, increased foreign assistance, and strengthened demand management contributed to the recent unprecedented accumulation of foreign exchange reserves, another important engine for the rise in reserves has been private external transfers.

However, there are some downside risks associated with the private transfers, and it should

be stressed that the private inflows that have materialized in the past couple of years are not

easy to explain. In particular, these inflows might well be linked to stock adjustment measures in the post-9/11 world, and might not continue on this high growth path or might

even reverse quickly. Also, we hope that by now we have stressed amply the private sector underinsurance problem, and the need for the public sector to take offsetting measures. All

these factors suggest that a high level of reserves is probably the best option at the present juncture, without necessarily implying that one should close the door on considering the other alternatives, especially if reserves continue to grow strongly.

Some of the problems with the original FCD scheme such as the provision of forward cover

by the SBP are not present in the new FCD scheme, but there remain some other outstanding issues in addition to the problems just discussed regarding the constraints on financial policies. In particular, one difficult issue that has emerged with the new scheme is that instead of using the scarce national savings to finance much-needed domestic investment, the

commercial banks have limited flexibility as to how to use the funds generated by the FCD deposits. Whereas sufficiently detailed bank-by-bank data are not available to allow one to

assess the open forex position of individual banks, it is the case that all banks respect the limit on their net foreign exchange position (10 percent of capital); in fact it appears that most are likely to hold long open positions. Furthermore, there are additional prudential constraints on such positions, e.g., FCDs must not exceed 20 percent of deposits and domestic foreign exchange-loans are strictly limited to export finance. Although the prudential measure of restricting FCDs to less than 20 percent of deposits serves some useful purposes, it does have a major disquieting feature in that it imposes an arbitrary constraint on the mobilization of savings in the domestic banking system. For instance, if expatriate Pakistanis had a particular need to keep their savings in foreign currency or there were policy-induced or other exogenous shocks, which were to shift the asset preferences of domestic residents in favor of foreign currency denomination (e.g., a greater need for a hedge against exchange rate depreciation or inflation), this policy measure runs the risk of imposing a ceiling on how much of the savings could go into the 
domestic

banking system. Thus, these potential savings would either not enter/remain in the country or

be kept outside the banking system as foreign currency notes. Also, the strict limit on domestic foreign exchange loans means that once a bank has exhausted its export finance - 23 -

options, it has to either keep the proceeds of its FCDs with the SBP or hold them as deposits

abroad. Indeed, most of the foreign exchange assets held by banks are deposits with

correspondent banks abroad, foreign bills purchased and discounted, and foreign

exchange

deposits with the SBP. In a country where paucity of savings is a major constraint and there

is an overriding need to promote financial intermediation and private investment, this

state of

affairs does not appear to be a very attractive option.

With regard to private savings, the modification of the NSS to facilitate a level playing

field

for commercial banks should be a high priority. The rates of profit paid on the NSS

instruments should be adjusted to be more in line with their risk and maturity

characteristics.

In this connection, a major step was taken in 2001 when the authorities decided to auction the

Pakistan Investment Bonds (PIB)27 and to use them as benchmarks for NSS rates, which resulted in significant reduction in public debt service. In the medium term, the government

can further improve public debt management and the by eliminating all on-tap instruments

and auction only a few instruments such as the treasury bills or the PIBs through primary dealers. The tax system continues to discriminate against banks, despite the reduction in income tax rates on banks in 2002 from 58 percent to 50 percent, as it is still above the corporate tax rate.28 While much more could fruitfully be said in this area, we shall confine ourselves in the following paragraphs to a few specific financial sector reforms that might be

helpful both with regards the mobilization of savings and the dollarization problem.

\section{B. Indexed Financial Instruments}

As mentioned in the literature on the "original sin” regarding currency mismatches in foreign

borrowing, there are several constraints that seemingly preclude borrowing abroad in domestic currency for most countries.29 Nevertheless, there is some debate about whether it

might be possible to overcome some of these difficulties if the emerging market countries were to issue inflation-indexed debt. On one side are the opponents of indexation, who point

out that if the policymakers were to develop a market for indexed debt, then they might 
end

up encouraging further indexation in the economy and that by reducing the costs of inflation

they may actually raise it in equilibrium, thereby worsening welfare because an economy

can

never be fully indexed.30 However, this cost has to be balanced against the cost of having foreign-currency-denominated debt, because the choice for emerging market economies is

not between nominal versus inflation indexed debt but rather between inflation indexed versus foreign currency debt. The proponents of indexed debt argue that self-fulfilling liquidity crises have adversely affected the macroeconomic performance of many emerging ${ }_{27}$ Pakistan Investment Bonds are long-term fixed-income bonds.

28 It should be noted that the income tax rates for banks have been reduced to 44 percent for the tax year 2003/04 and will be further reduced to the corporate tax rate of 35 percent by tax year 2006/07.

29See Eichengreen and Hausmann, 1999, and Hausman, Panizza, and Stein, 2001.

30 Fischer and Summers, 1989, present a model where social welfare can indeed decrease by the introduction of

measures that reduce the costs of inflation.

- 24 -

market countries, and if it can be shown that a market for inflation-indexed debt instruments

would serve to attenuate these crises, then a case could be made for these types of instruments, notwithstanding the well-known problems associated with indexation such as

structural rigidities and inflation inertia.

Borensztein and Mauro (2002) discuss how countries can self-insure against economic growth slowdowns by issuing GDP-indexed bonds. They simulate the effects of GDPindexed

bonds under different assumptions about fiscal policy reaction functions, and their results show that these bonds would help to substantially reduce the likelihood that debt/GDP paths become explosive. The insurance premium would likely be small, because crosscountry comovement of GDP growth rates is low and cross-country GDP growth risk is thus largely diversifiable for an investor holding a portfolio of GDP-indexed bonds. The authors

emphasize that while their paper focuses on GDP risk for the sake of simplicity, it should be

clear that there are many sources of risk affecting the debt-service capacity of emerging markets. For example, one could instead focus on the external terms of trade risk, which would suggest the idea of debt instruments that are adjusted to the world price of some key commodity. Chamon (2001) develops a model to analyze the implications for financial crises of denominating external borrowing in terms of a nontraded good, which would be similar to

having a domestic inflation indexed debt instrument. Chamon's model is designed to 
analyze

the implications for self-fulfilling liquidity crises when foreign debt is denominated in terms

of the price of nontraded goods. The analysis shows that a major advantage of having the indexed debt instrument is that it provides a mechanism that adjusts the value of the debt so

that all creditors can be repaid in the event of a debt run. A liquidity crises may be avoided,

because when there is a decline in the value of the debt following the decline in the price of

nontraded goods, then all creditors share in this loss because they hold indexed debt.

Furthermore, since the creditors will receive an amount that is independent of the order in which they collect their debts, they will have not have any incentives to join in a debt run. In

other words, the mechanism for avoiding liquidity crises relies on the decline in the relative

price of the nontraded good in anticipation of the liquidation of the traded good production, if

there were to be a debt run.

To some observers, however, any recommendation for any sort of indexation in the economy

would appear to be akin to one which gives up the fight against inflation and sees the option

as one of trying to minimize the costs of inflation by indexing particular assets. One cost that

has been frequently emphasized in the literature relates to the weakening of the will to continue the fight against inflation: results derived from theoretical economic models as well

as empirical evidence from countries that have practiced indexation show that changes

that

reduce the social costs of inflation increase the equilibrium inflation rate and tend to worsen

social welfare. This point takes on added importance in the Pakistani context because there

are some widely cited studies, which have argued that there is greater scope for seigniorage

in the Pakistan economy than has been realized by the Government. It would take us too far a

field to discuss all of the issues involved in the wage and price indexation literature, and we

shall confine ourselves here to referring the reader to the many studies that have been done in

- 25 -

this area.31 In particular, Mirakhor and Zaidi (2004) have provided several counterarguments

against inflationary financing of the budget deficit in Pakistan. Their study provides both 
the

analytical underpinnings for the case for pursuing noninflationary fiscal and monetary policies as well as points to several weaknesses in the empirical studies purporting to make a

case for higher inflation in Pakistan. One point that bears emphasis is the evidence from cross-country studies that once indexation becomes popular in the economy, it becomes very difficult to reverse the trend toward increasing indexation. In the present context, we would

like to stress that it is necessary to distinguish between indexing that decreases the costs of

unanticipated inflation to the government from that which does not. In particular, indexing of bonds reduces the gains from unanticipated inflation to the government, because the mechanism for eroding the real value of public debt is thwarted, and insofar as that advantage

is checked, this particular financial indexation would not necessarily encourage higher inflation.

There are some other difficulties associated with indexed instruments, which might be worth

noting. In particular, if there were to be differential rates of indexation on bank loans and deposits, then this would result in exposure to inflation risk that must be borne by the banking system, or if they were to become particularly large, by the public sector in terms of

bank bailouts. However, the need to address these issues does not at all mean that the introduction of the innovative financial instruments faces insurmountable obstacles or has to

be delayed for a long time. On the contrary, we think that this is an opportune time to effect major structural reforms to place the financial system on a sound footing. Until such time as

the innovative schemes are introduced in the banking system, there remains the question of

what to do with the large increase in FCDs. The current set-up of tight limits on the banks'

net foreign exchange position, as well as limiting domestic foreign exchange loans to export

finance, has the major advantage of controlling foreign exchange risks in the banking system.

However, this advantage has to be compared with the foregone benefits that would come from using the savings for investment in physical capital in the domestic economy. Put it differently, how does one trade off these two combinations of pluses and minuses: on the one

hand, there is the low risk in the domestic banking system but at the cost of having savings

going abroad in the form of low return (partly because of low risk) foreign financial 
assets;

on the other hand, one can count on higher investment rates in the economy to bolster the growth performance but then also face the potential problem from increasing the banks' exposure to foreign exchange and credit risks. It might require another paper to answer these questions fully, but based on the extensive discussion about the savings-investment constraint in Mirakhor and Zaidi (2004), as well as the analysis we have provided in Section III above

on the cost of acquiring international reserves and sustaining growth-oriented adjustment programs, we would put a lot of emphasis on adequate international reserve holdings or using

the savings for investment purposes as long as there are adequate safeguards.32 ${ }_{31}$ See, for example, Fischer and Summers, 1989.

32 To the extent that there might be further dollarization in the banking system on both the asset and liabilities

sides, the SBP will have to be vigilant in ensuring that nonperforming loans (NPLs) do not become a problem, particularly with regard to the strategies followed by the banks and the credit risks on their dollar loans. Banking supervision entails a feedback-control process involving continuous and timely interaction between the

central bank and the financial institutions, particularly the review and analysis of data submitted by the (continued...)

- 26 -

\section{ConCLUSIONS}

This paper has analyzed how the large volume of short-term foreign currency deposits and

the specific institutional characteristics of those deposits had made the Pakistan economy highly vulnerable to exogenous shocks. While emphasizing the importance of linking capital

account liberalization to the appropriate sequencing of domestic financial reforms (and bank supervision), the paper also focused on the problem that the FCD scheme had created yet another channel for government borrowing. The analysis showed that fiscal sustainability in

a "closed" system may be very different from sustainability in a more "open" system, and there is a need to think of these issues in terms of total balance sheet vulnerability. The main reason for the reliance on short-term capital had been the large fiscal deficits, and there is a continuing need for strengthening financial policies to promote internal and external stability.

The authorities should continue to integrate the economy with international financial markets, because foreign capital inflows can help to finance investment and provide opportunities for risk diversification to residents, but they will have to be extra vigilant on the

fiscal front. To quote from Krueger (2004): "It is clear from experience that large unsustainable fiscal deficits and open capital markets make uncomfortable bedfellows. 


\section{Large}

fiscal deficits pose increasing risks for the financial sector as capital flows are freed up.

And

here I want to emphasize that deficits financed in large part by domestic creditors can be especially dangerous." 33

The vulnerability of Pakistan to shocks that adversely affected its balance of payments position depended on the terms and conditions under which it could obtain international liquidity. The reliance on FCDs for even the rather limited reserve accumulation that had been done meant that the country's efforts to improve economic performance were constrained by having borrowed rather than owned international reserves. Even when there

was access to private credit markets, there was the need for periodic refinancing of the borrowing undertaken to finance reserve holdings, and the costs of such financing had exhibited marked volatility. Trends in net borrowing from private creditors illustrate clearly the changing perceptions of Pakistan's creditworthiness and the consequent availability of

funds. Thus, the size of private foreign capital inflows, including FCDs, expressed as a ratio to GDP or to imports of goods and services varied considerably over time. When the country

commercial banks. Hence, SBP should continue to develop its ability to be well-informed in a timely way about the trends and any undesirable developments in the banking industry and be able to take appropriate and

rapid policy measures when necessary. Further progress should be made to gather relevant data from the supervised institutions, with the focus on obtaining less frequent but more meaningful information. In this connection, financial institutions should provide comprehensive reports on a quarterly basis, which would reflect their financial positions accurately. In particular, there should be complete income statements in the quarterly reports, which would show details on all accruals, amortization, and updated reserves for nonperforming assets. It is in this respect that SBP should intensify the work on an early warning system for any deterioration in the loan portfolios of banks, which would be based on a sufficiently accurate and comprehensive database. The early warning system would rely in the first instance on off-site prudential supervision with a view to identifying problem banks requiring additional supervisory attention. Also, SBP should have a well functioning system for financial analysis of the quarterly returns from banks. 33 Krueger, 2004, p. 5.

- 27 -

had adequate holdings of international reserves and access to other sources of international liquidity, it could sustain a smooth adjustment program because it could finance its way out of temporary external shocks. However, when there was inadequate liquidity, even temporary shocks had forced the country to modify its adjustment policies; this choice was often not desirable, because a sharp tightening of monetary policy would depress investment spending. This paper has emphasized that international reserve targets should be set not only in relation to variations in the volumes of foreign trade but also keeping in view the growth in 
short-term liabilities. As well, the analysis has pointed to the need for measures to enhance

international liquidity, including measures that would make domestic currency denominated

assets relatively more attractive to hold. The reduction in inflation, together with adequate

rates of return on domestic currency deposits, can be expected to lead to a sustained lowering

of the reliance on FCDs and the dollarization of the economy. To be sure, one would expect

to have some dollarization in the economy even when inflation rates are low and returns on

domestic assets are more competitive than in the past, both because of the large workers' remittances and because domestic residents would want to diversify their portfolios. However, the volumes of foreign liabilities would be sharply lower, and the attendant costs

and risks would be of a different order of magnitude than those discussed in this paper. - 28 -

Table 1. Basic Economic Indicators, 1973-2003

GNI growth Inflation

Current

Account

Deficit

International

Reserves REER

Official

Exchange Rate

Year (percent) (end-ofperiod)

(percent of

GDP)

(months of

imports of G\&S)

(percentage

change)

(Rupees per

dollar)

$197324.3323 .07-1.405 .93$ n.a. 9.88

$197429.9026 .66-10.043 .60$ n.a. 9.88

$197528.4220 .90-9.182 .09$ n.a. 9.88

$197618.727 .16-6.332 .65$ п.а. 9.88

$197716.4010 .13-4.122 .30$ n.a. 9.88

$197821.426 .14-4.531 .77$ n.a. 9.88

$197911.138 .27-4.280 .83$ n.a. 9.88

198020.5411 .94 -3.25 1.26 n.a. 9.88

$198119.1811 .88-2.861 .5212 .469 .88$

$198216.165 .90-1.272 .34-8.3912 .84$

$198315.536 .36-1.844 .03-3.4213 .50$

$198413.776 .09-3.572 .202 .1215 .36$

$198511.125 .61-2.661 .58-6.6015 .98$

$19868.903 .51-1.731 .58-17.4817 .25$

$19879.534 .68-2.601 .15-11.0217 .45$

$198815.718 .84-3.450 .83-1.5018 .65$ 
$198913.107 .84-3.591 .00-6.3921 .42$

$199011.789 .05-3.540 .60-6.5421 .90$

$199116.8311 .79-3.330 .98-1.8224 .72$

$199217.029 .51-4.301 .18-1.4325 .70$

$199310.279 .97-4.811 .56-0.3530 .12$

$199416.5512 .37-3.613 .77-2.2430 .80$

$199520.1212 .34-5.542 .09-0.6534 .25$

$199612.3910 .37-6.440 .69-1.9640 .12$

$199714.0111 .38-4.221 .353 .0844 .05$

$199810.146 .23-3.191 .33-3.4745 .89$

$19999.784 .14-2.792 .01-5.7251 .78$

$20007.534 .37-1.891 .711 .1858 .03$

$20017.673 .150 .424 .12-6.9560 .86$

20028.553 .294 .148 .313 .9558 .53

$200314.702 .913 .279 .27-4.9457 .22$

Period Averages

1973-79 21.4714 .62 -5.70 2.74 n.a. 9.88

1980-89 14.35 $7.27-2.681 .75-4.4715 .22$

1990-99 $13.899 .72-4.181 .56-2.1134 .93$

2000-03 9.61 $3.431 .495 .85-1.6958 .66$

Sources: World Economic Outlook and International Financial Statistics Databases.

- 29 -

Table 2. Foreign Currency Deposits and Official Reserves, 1990/91-2003/04

(In millions of U.S. dollars)

Fiscal Year

$1 /$

NRFCD

2/

RFCD

3/

TFCD

4/

(a)

International

Reserves 5/

(b)

Difference

(b-a)

1990/1991 2,203 389 2,592 1,390 -1,202

1991/1992 1,989 1,707 3,696 1,761 -1,935

1992/1993 2,227 2,250 4,478 1,369 -3,109

1993/1994 2,920 3,002 5,923 3,337 -2,586

1994/1995 3,191 3,384 6,575 3,730 -2,845

1995/1996 4,158 4,147 8,305 3,251 -5,054

1996/1997 4,352 5,491 9,843 1,977 -7,866

1997/1998 3,655 6,024 9,679 1,736 -7,943

1998/1999 2,493 2,354 4,848 2,371 -2,477

1999/2000 1,641 1,303 2,944 2,150 -794

2000/2001 1,184 1,069 2,253 2,666 413

2001/2002 424770 1,194 5,439 4,245

2002/2003 62232293 10,700 10,407

2003/2004 46175221 12,114 11,893

Period Averages

1990/91-1999/00 2,883 3,005 5,888 2,307 -3,581

2000/01-2002/03 557690 1,247 6,268 5,022 
Source: Pakistani authorities.

1/ Fiscal year ends on June 30. Observation for 2003/04 represents the data of February 2004.

2/ Nonresident foreign currency deposit.

3/ Resident foreign deposit.

4/ Total foreign currency deposit.

5/ International reserves include gold, SDR, foreign exchange reserves, and authorized dealers' balances.

- 30 -

Table 3. Resident Foreign Currency Deposits (RFCD) and Money Supply, 1990/912003/04

Fiscal Year 1/ M2 RFCDs Ratio of RFCD

(In millions

of Rupees)

(In millions

of Rupees)

to M2

(In percent)

1990/91 368,783 9,957 2.70

1991/92 480,644 44,382 9.23

1992/93 567,169 65,712 11.59

1993/94 662,805 96,138 14.50

1994/95 772,998 108,654 14.06

1995/96 938,680 145,958 15.55

1996/97 1,053,234 222,882 21.16

1997/98 1,206,320 278,556 23.09

1998/99 1,280,546 120,917 9.44

1999/00 1,400,632 112,475 8.03

2000/01 1,526,044 154,154 10.10

2001/02 1,761,370 157,456 8.94

2002/03 2,078,769 126,138 6.07

2003/04 2/ 2,312,307 148,282 6.41

Period Averages

1990/91-1999/00 873,181 120,563 12.94

2000/01-2002/03 1,788,728 145,916 8.37

Source: Pakistani authorities.

1/ Fiscal year ends on June 30.

2/ Latest available data.

- 31 -

Table 4. External Debt, 1991/92-2003/04 1/

. Period Averages

1991/92 1992/93 1993/94 1994/95 1995/96 1996/97 1997/98 1998/99 1999/00 2000/01 2001/02 2002/03

Projected

2003/04

$1991 / 92-$

$1999 / 00$

2000/01 -

2003/04

(In millions of U.S. dollars)

Total 22,880 25,913 28,990 31,330 32,709 33,908 33,545 34,046 35,321 35,332 35,609 35,123 35,452 30,960 35,379

Public and publicly guaranteed 2/ 22,507 24,479 26,098 28,108 28,121 28,709 29,000 29,318 31,031 31,935 32,769 32,608 33,689 27,486 32,750

Private 373 1,434 2,892 3,222 4,588 5,199 4,545 4,728 4,290 3,396 2,840 2,515 1,763 3,474 2,629

(In percent of GDP)

Total 46.8 50.1 55.6 51.4 51.4 54.153.758.158.0 60.1 60.151.0 45.7 53.2 54.2

Public and publicly guaranteed 2/ 46.1 47.3 50.1 46.1 44.2 45.8 46.4 50.0 50.954.3 55.3 47.4 43.4 47.4 50.1

Private 0.8 2.8 5.5 5.3 7.2 8.3 7.3 8.1 7.0 5.8 4.8 3.7 2.3 5.8 4.1

Foreign currency deposits $3 / 4.14 .35 .65 .26 .56 .95 .84 .32 .72 .00 .70 .10 .15 .10 .7$

Other 4/ 2.72 .52 .83 .32 .24 .14 .66 .05 .55 .16 .02 .12 .63 .73 .9

(In percent of current foreign exchange receipts)

Total 202.2 240.9 268.0 256.7 260.1 262.4 251.0 310.2 301.4 273.9 250.6 178.7 171.4 261.4 218.6

Public and publicly guaranteed 2/ 198.9227 .5241 .2230 .3223 .6222 .1217 .0267 .2264 .8247 .6230 .6165 .9162 .8232 .5201 .7

Private 3.313 .326 .726 .436 .540 .234 .043 .136 .626 .320 .012 .88 .528 .916 .9

Foreign currency deposits 17.6 20.7 27.0 26.1 33.1 33.7 27.3 22.7 14.0 9.2 3.0 0.3 0.2 24.73.2

Other 4/ 11.812 .013 .616 .710 .919 .821 .432 .028 .623 .224 .87 .29 .718 .516 .2

(In percent of private external debt) 
Foreign currency deposits 533.3155 .3101 .099 .090 .683 .780 .452 .738 .334 .914 .92 .52 .6137 .213 .7

Other 4/ 356.9 90.0 50.7 63.1 29.9 49.2 62.9 74.3 78.2 88.1 124.3 56.3 114.0 95.195.7

Sources: State Bank of Pakistan; Ministry of Finance; and Federal Bureau of Statistics.

1/ External debt after rescheduling /restructuring as of June 30 in each year.

2/ Including central bank.

3/ Nonresident foreign currency deposits.

4/ Short-term debt; includes commercial bank and IDB borrowing, Foreign Exchange Bearer Certificates (FEBC), Dollar Bearer

Certificates (DBC), and State Bank of Pakistan (SBP) liabilities (including swaps).

- 32 - APPENDIX I

APPENDIX I

\section{CABALlero-Krishnamurthy Model}

The objective of this appendix is to clarify the structure and behavior of a macroeconomic

model for a small open economy developed by Caballero and Krishnamurthy, as the key insights from this model were used in the main text to point out the constraints from the dollarization of the economy, most notably in the form of large foreign currency deposits in

the banking system. The model has been dubbed the dual liquidity model by Caballero and

Krishnamurthy to emphasize the financial constraints affecting borrowing and lending among agents within the economy, and constraints affecting borrowing from foreign lenders. Since the model has been discussed extensively in a series of papers by Caballero and Krishnamurthy (2001, 2003, and 2004), the discussion in this section is brief and the reader is referred to the papers just mentioned for details. The focus of the present exposition is on those features of the model that are most relevant for the analysis of international and domestic liquidity constraints in the Pakistan economy.34 The model consists of the following assumptions, and is represented by equations (1)(11) in

Table A1. There are three periods in the model: date 0 is the fully flexible period in which agents make investments and financing decisions; date 1 is the near financial crisis situation

in which the domestic agents have sufficient collateral to borrow from other domestic agents, but cannot borrow from foreigners because the country has a shortage of international collateral; date 2 is the final date when firms pay their debt obligations. There are two states of the world at date 1 , denoted $b$ and $g$, which occur with probabilities $ð$ and 1 - $ð$. In the $b$-state, firms experience adverse liquidity shocks, and face binding financial constraints, while in the $g$-state, there are no shocks and financial constraints are not binding. The plants of one-half of the firms receive a shock with probability 0.5 at date 1 that lowers output from

A to $a$. This productivity decline can be offset by investing $k$ (goods, which would generate

the date 2 output depicted in equation 1 . Equation 2 is the assumption that the return on 
investment exceeds the international interest rate, while in equation 3 it is assumed that the

firm first borrows against its net international collateral from foreigners. Once the firm has

used its international collateral, it finances the remainder from other domestic firms that did

not receive the shock, which are labeled intact firms. In the horizontal view, the distressed

firms are constrained in meeting their financing needs because they have limited liability, that is, their total liquidity of $n a k w+$ is insufficient to meet the production shock. This is shown in equation 4 where intact firms borrow from foreigners against the international collateral of $n W$ and lend to distressed firms against the domestic collateral of $a k$. In this ${ }_{34}$ While there is still some disagreement on the causes underlying the financial crises in emerging markets, in

recent years most researchers have emphasized that one of the most salient feature was the contracting of debt denominated in foreign currency. Thus, the third generation models of currency crisis focus on the balance sheet mismatches that led to bankruptcies and other dislocations in the real sector, which had feedback effects that served to amplify the downturns. Like other third generation models of the currency-balance sheet channel, the

dual liquidity model also relies on the assumption that firms contract dollar denominated debt, and provides a rigorous analysis of why firms choose (or perhaps the better word would be must) to take on dollar debt. - 33 - APPENDIX I situation, the international financial constraint is not binding for intact firms, and the interest rate they charge against domestic collateral is equal to the international interest rate (equation

(5)). Accordingly, total investment in determined by the financial constraints of the individual firms, as shown in equation (6), where $\mathrm{H}$ denotes the horizontal equilibrium. Caballero and Krishnamurthy denote this equilibrium situation as the horizontal view, because the domestic interest rate is equal to the international interest rate, and not affected by the quantity of domestic loans; a distressed firm can borrow as long as its domestic financial constraint is not binding.

Table A1: Caballero-Krishnamurthy Model

1. ( ) ( ) Ak k a $k$ A $\Leftarrow \Leftarrow .+=((\sim$, where $a A-\square \Downarrow$.

2. $1-$. > *

${ }_{1} i$

3. $f w w_{n}-\square \Downarrow$

4. $a k w n$

2

1

2

$1>$ 


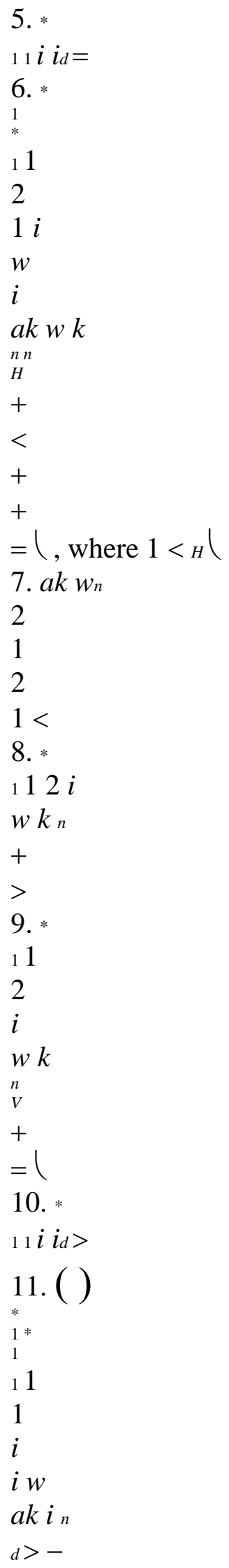


In contrast to the horizontal view, the vertical view is the situation where the international supply of funds is vertical, because there is a shortage of country-wide international liquidity,

and the inequality in equation (4) is reversed to give equation (7). Although distressed firms have enough domestic liquidity to pay for the international liquidity of the intact firms, the international liquidity is scarce relative to the financing need, as shown in equation (8). In - 34 - APPENDIX I

this situation, investment is determined by the stock of international liquidity and domestic

liquidity does not appear in equation (9), where superscript V stands for the vertical equilibrium. In the vertical view, the interest rate on loans against domestic collateral is greater than the international interest rate, because the intact firms are borrowing up to their

maximum capacity from foreigners and lending to domestic firms against domestic collateral

(equation (10)). Since the international collateral is the binding constraint the loan supply curve becomes vertical beyond this point. The credit market is segmented in this region with

$d$ $1 i>*$

$1 i$ but it does not exceed . -1 , which is the marginal product of investment for the distressed firms, as borrowing costs cannot exceed the marginal product. Equation (11) is the

condition that $d$

1 i lies between *

$1 i$ and .-1 after some rearrangement.

Caballero and Krishnamurthy (2001) sketch a model in which collateral aggregation is done

not in the domestic debt market but in the banking system, which is more relevant to the case

of the FCD problem in Pakistan. In this version of the model, intact firms deposit funds with

the banks, while distressed firms take loans from the banks. Since the banks act as intermediaries in this model and intact firms do not directly purchase the debt claims of the

distressed firms, sharp declines in asset prices lead to problems in the banking system and not

in the domestic debt market.35 As banks experience declining asset values, their ability to aggregate collateral is weakened, which leads to further declines in asset prices and economic activity.36

Caballero and Krishnamurthy pose the dollar debt problem as one of microeconomic underinsurance with respect to country-wide aggregate shocks. Their analysis shows that 
denominating external debt in domestic currency is equivalent to contracting the same amount of dollar-debt, but then complementing with insurance against shocks that depreciate

the equilibrium exchange rate. They also derive the result that when there are countrylevel international financial constraints, it would be optimal to purchase such insurance even if all

agents are risk neutral. However, if domestic financial constraints also exist, there is the problem that domestic residents will undervalue the social benefits of contracting insurance against country-wide shocks. Furthermore, foreign lenders will reinforce the underinsurance problem by reducing their participation in domestic financial markets.

The analysis helps to clarify the constraints imposed on stabilization policies in Pakistan by

the FCD scheme, particularly with regard to the effect of monetary policy on the exchange

35 In the canonical model, distressed firms access the international collateral of intact firms by borrowing from

them against their domestic collateral. The implicit assumption in the model without banks is that this collateral aggregation is done in a perfectly functioning public debt market. In other words, distressed firms issue debt

claims in the domestic market secured by domestic collateral, while intact firms issue debt claims to foreign investors secured by international collateral. The intact firms then use the proceeds from this issue to purchase the debt claims of the distressed firms.

${ }_{36}$ When banks are included in the model, it is the banks that issue claims to foreign investors against balance

sheets that are partially backed by international collateral. When the banks provide these funds to distressed firms, they act as the intermediary for the intact firms extending credit to distressed firms against their domestic collateral.

- 35 - APPENDIX I

rate. In the vertical region, if the SBP were to adopt an expansionary monetary policy stance, it would not be able to loosen the international liquidity constraint, but instead the price of

domestic liquidity would decline in relation to the price of international liquidity.37 In this way, monetary policy would have distributional effects, because it would affect the allocation of the return on investment between lenders and borrowers. However, the SBP could not conduct countercyclical monetary policy in the vertical region, because investment by the distressed firms would be constrained by the international liquidity. Any attempt by the SBP

to expand monetary policy would depreciate the exchange rate, and since the SBP would be

concerned not only with the balance sheets of the firms, but also its own open foreign exchange position and the inflation target, it would tend to favor a policy that supported 
the

exchange rate.

The SBP's attempts to stabilize the exchange rate in order to hit the inflation target and protect its balance sheet in the vertical region had the unintended effect of distorting the private sector's insurance decisions concerning international liquidity shortages. Since countercyclical monetary policy was ineffective in stabilizing output in the vertical region, the domestic agents (firms, banks, etc.) would take into account the SBP's defense of the exchange rate when making their decisions about hedging against adverse shocks in the vertical situation. Insofar as the domestic agents expected limited exchange rate flexibility

and a smaller decline in the value of domestic liquidity in relation to international liquidity, they would tend to underinsure against the possibility of finding themselves with too little international liquidity in the bad states of nature. In contrast, if the SBP had sufficiently large international reserve holdings to demonstrate the credibility and efficacy of countercyclical

monetary policy, it would have provided the private sector with the right incentives to insure against international liquidity shortages.

${ }_{37}$ Since international liquidity would be the binding constraint in the vertical region, the impact of monetary

tightening would be in terms of the lowering of the value of the domestic collateral that borrowers could offer to

dollar-lenders.

- 36 -

\section{REFERENCES}

Bartolini, Leonardo, and Allan Drazen, 1997, "Capital Account Liberalization as a Signal,"

American Economic Review, Vol. 87, No. 1, pp. 138-154.

Borensztein, Eduardo and Paolo Mauro, 2002, "Reviving the Case for GDP-Indexed Bonds,”

IMF Policy Discussion Paper No. PDP/02/10, (Washington: International Monetary

Fund).

Caballero, Ricardo, 2003, “The Future of the IMF,” American Economic Review, Papers and

Proceedings, (May), No. 93(2), pp. 31-38.

Caballero, Ricardo and Arvind Krishnamurthy, 2001, "International and domestic collateral constraints in a model of emerging market crises,” Journal of Monetary Economics, No. 48, pp. 513-548.

— , 2003, "Excessive Dollar Debt: Underinsurance and Domestic Financial Underdevelopment, Journal of Finance, April, No. 58(2), pp. 867-893.

_ , 2004, "Exchange Rate Volatility and the Credit Channel in Emerging Markets: A

Vertical Perspective," mimeograph, Massachusetts Institute of Technology. Available 
at http://web.mit.edu/caball.

Chamon, Marcos, 2001, “Why Don’t We Observe Foreign Lending to Developing Countries

in their Currency, Even When Indexation to Inflation is Available?” mimeograph, Harvard University.

Chang, Roberto and Andres Velasco, 2000, "Financial Fragility and the Exchange Rate

Regime,” Journal of Economic Theory, No.92, pp. 1-34.

Eichengreen, Barry and Ricardo Hausmann, 1999, “ Exchange Rates and Financial

Fragility,” NBER Working Paper No. W7418.

Fischer, Stanley, and Lawrence Summers, 1989, "Should Governments Learn to Live with

Inflation?” American Economic Review, Vol. 79, pp. 283-388.

Flood, Robert and Peter Garber, 1984, "Collapsing Exchange-rate Regimes: Some Linear Examples,” Journal of International Economics, No. 17, pp. 1-13.

Flood, Robert and Nancy Marion, 2001, “A Model of the Joint Distribution of Banking and

Exchange-Rate Crises,” IMF Working Paper 01/213. (Washington: International Monetary Fund). , 2002, "Holding International Reserves in an Era of High Capital Mobility," IMF Working Paper 02/62. (Washington: International Monetary Fund).

- 37 -

Goldsbrough, David and Iqbal Zaidi, 1986, "Transmission of Economic Influences from Industrial to Developing Countries," Staff Studies for the World Economic Outlook, (Washington: International Monetary Fund,) July, pp. 150-195.

Greenspan, Alan, 1999, “Currency Reserves and Debt,” Bank for International Settlement Review, No. 47.

Hausman, Ricardo, Ugo Panizza, and Ernesto Stein, 2001, Why Do Countries Float the Way

They Float? Journal of Development Economics 66, pp. 387-414. Hook, Andrew, 1997, Savings in Pakistan: Practice and Policy, (Karachi: State Bank of Pakistan.

International Monetary Fund, 2001, Pakistan: Selected Issues and Statistical Appendix, IMF

Country Report No. 01/11, (Washington).

— 2002a, Pakistan: Second Review Under the Three-Year Arrangement Under the Poverty Reduction and Growth Facility and Request for Waiver of Performance Criterion-Staff Report; Staff Statement; News Brief on the Executive Board Discussion; and Statement by the Executive Director for Pakistan, IMF Country Report No. 02/141, (Washington).

— 2002b, Pakistan: Selected Issues and Statistical Appendix, IMF Country Report No. 02/247, (Washington).

IMF Independent Evaluation Office, 2002, "Evaluation of Prolonged Use of IMF Resources," (Washington). Iqbal, Zubair and Abbas Mirakhor, 1987, Islamic Banking, Occasional Paper No. 49. (Washington: International Monetary Fund). Krueger, Anne O., “An Intolerable Surge? International Capital Flows and the Indian 
Policy

Response,” Address to National Institute for Bank Management, Pune, India, January 21, 2004. Available at http://www.imf.org

Krugman, Paul, 1979, “A Model of Balance of Payments Crises,” Journal of Money, Credit

and Banking, XI, pp. 311-325.

, 1999, "Balance Sheets, the Transfer Problem, and Financial Crises,” in

International

Finance and Financial Crises: Essays in Honor of Robert P. Flood, Jr. (Washington:

International Monetary Fund).

Mirakhor, Abbas, 1990, “The Progress of Islamic Banking: The Case of Iran and

Pakistan,"

in Islamic Law and Finance, edited by Chibli Mallat, Graham \& Trotman, London.

- 38 -

— Staff Studies for the World Economic Outlook (Washington: International Monetary Fund, pp. 59-97. and Iqbal Zaidi, 2004, "Fiscal Deficits and Macroeconomic Instability in

Pakistan”

mimeograph, (Washington: International Monetary Fund).

Obstfeld, Maurice, 1994, “The Logic of Currency Crises," Cahiers Economiques et Monétaires, No. 43, pp. 189-213.

—, 1996, "Models of Currency Crises with Self-Fulfilling Features,” European

Economic Review, No. 40, pp. 1037-1047.

World Bank, 2002, "Poverty in Pakistan: Vulnerabilities, Social Gaps, and Rural

Dynamics,”

Green Cover: Report No. 24296-PAK, (Washington).

Yaqub, Muhammad, 2003, "Political and Economic Aspects of Banking Sector Reforms in

Pakistan,” mimeograph, (Washington: World Bank). 